by George M. Gibson ${ }^{l}$, Paul A. Henson ${ }^{l}$, Narelle L. Neumann ${ }^{l}$, Peter N. Southgate ${ }^{l}$ and Laurie J. Hutton ${ }^{2}$

\title{
Paleoproterozoic-earliest Mesoproterozoic basin evolution in the Mount Isa region, northern Australia and implications for reconstructions of the Nuna and Rodinia supercontinents
}

\footnotetext{
${ }^{1}$ Geoscience Australia, GPO Box 378, Canberra, ACT 0200, Australia. E-mail: george.gibson@ga.gov.au; paul.henson@ga.gov.au; peter.southgate@ga.gov.au

${ }^{2}$ Geological Survey of Queensland, Department of Employment, Economic Development and Innovation, GPO Box 15216 City East, QLD 4002, Australia.E-mail: laurie.hutton@deedi.qld.gov.au
}

Paleoproterozoic-earliest Mesoproterozoic sequences in the Mount Isa region of northern Australia preserve a 200 Myr record (1800-1600 Ma) of intracontinental rifting, culminating in crustal thinning, elevated heat flow and establishment of a North American Basin and Range-style crustal architecture in which basin evolution was linked at depth to bimodal magmatism, high temperature-low pressure metamorphism and the formation of extensional shear zones. Rifting initiated in crystalline basement $\geq 1840 \mathrm{Ma}$ old and produced three stacked sedimentary basins (1800-1750 Ma Leichhardt, 1730-1670 Ma Calvert and 1670-1575 Ma Isa superbasins) separated by major unconformities and in which depositional conditions progressively changed from fluviatilelacustrine to fully marine. By 1685 Ma, a deep marine, turbidite-dominated basin existed in the $E$ and basaltic magmas had evolved in composition from continental to oceanic tholeiites as the crust became increasingly thinned and attenuated. Except for an episode of minor deformation and basin inversion at c. $1640 \mathrm{Ma}$, sedimentation continued across the region until onset of the Isan Orogeny at $1600 \mathrm{Ma}$. A near-identical record of crustal thinning and basaltic magmatism accompanied basin formation (lower Willyama Supergroup) in the formerly contiguous Broken Hill region from 1730-1670 Ma. This was followed by further extension and a second phase of basin development that lasted until at least 1640 Ma. Modern-day rifted continental margins preserve a comparable record of crustal thinning and nearcontinuous basin formation over 100-200 Myr timescales, supporting suggestions that the late Paleoproterozoic-early Mesoproterozoic rift basins of Mount Isa and Broken Hill similarly evolved to continental breakup and formed part of a continental margin sequence no later than $1640 \mathrm{Ma}$ and possibly as early as $1670 \mathrm{Ma}$. This rifted margin predates assembly and breakup of the Neoproterozoic Rodinia supercontinent to which Australia once belonged and best accords with a pre-Rodinia, SWEAT-like supercontinent (Nuna) that matches the E-facing late Paleoproterozoic-early Mesoproterozoic rift sequences of eastern Australia against rocks of comparable age in western Canada. Reconstructions of Rodinia (AUSWUS) based on the distribution of Grenville-age orogenic belts that coincidently position the continental rift sequences of Broken Hill along strike from more juvenile 1700-1650 Ma accreted terranes in the SW United States (Yavapai and Mazatzal provinces) are only possible if the proposed alignment of terranes is not original but an artefact of Neoproterozoic supercontinent assembly. The SWEAT hypothesis avoids this complication but, like AUSWUS, presupposes that eastern Australia and western Laurentia remained juxtaposed throughout the Mesoproterozoic until onset of Rodinia breakup after $830 \mathrm{Ma}$.

\section{Introduction}

Reconstructions of the Neoproterozoic supercontinent Rodinia, and its Paleoproterozoic predecessor Nuna (or Columbia by which it is sometimes known) (Ernst et al., 2008; Rogers and Santosh, 2009; Zhao et al., 2002), are typically based on matching conjugate 
continental rift margins with similar geological histories and polar wander paths (e.g., Dalziel, 1991; Wingate et al., 2002). For the prePhanerozoic east Australian rift margin, potential matches have been sought in western Laurentia (Figure 1), South China and Mexico where basaltic dyke swarms, syn-rift sedimentary sequences and older basement rocks of the same age and isotopic composition are known to occur (e.g., Burrett and Berry, 2000; Karlstrom et al., 2001; Moores, 1991; Park et al., 1995; Thorkelson et al., 2001; Wang et al., 2011; Wingate et al., 2002). Australian basement rocks for which Laurentian equivalents have already been proposed (e.g., Burrett and Berry, 2000; Karlstrom et al., 2001; Betts et al., 2008) include the late Paleoproterozoic-early Mesoproterozoic basin sequences of Broken Hill and Mount Isa (Figure 1a), both of which lie just inboard of the Tasman Line (Figure 1b) and E of which Proterozoic continental crust is thought not to occur. Although geographically distant from each other (Figure 1), these two regions exhibit strikingly similar geological histories and potential field signatures (Figure 2a) (Baker et al., 2010; Gibson et al., 2008; Giles et al., 2002; Henson et al., 2011; Laing, 1996). This has led many researchers to propose that their constituent rock sequences were formerly contiguous (Figure $2 b$ ) and originated through extensional processes in the same back-arc basin (Betts and Giles, 2006; Betts et al., 2008; Gibson et al., 2008; Giles et al., 2002).

Some researchers have further argued that this basin was located above a $\mathrm{N}$-dipping subduction zone along the southern margin of the Australian craton (Betts et al., 2008, 2011; Giles et al., 2002). A nearidentical tectonic environment has been proposed for the late Paleoproterozoic-early Mesoproterozoic basins of interior North America (e.g., Thelon, Athabasca) $\mathrm{N}$ of the Cheyenne suture (Duebendorfer and Houston, 1987; Karlstrom et al., 2001; Karlstrom and Bowring, 1988; Rainbird et al., 2007; Thorkelson et al., 2005), reinforcing earlier observations that the Paleo-Mesoproterozoic rocks of eastern Australia and western Laurentia share too many geological similarities to have developed in isolation of each other (e.g., Bell and Jefferson, 1987; Betts et al., 2008, 2011; Dalziel, 1991). Rather, there is a strong possibility that the older 1800-1600 Ma rift basins of eastern Australia and western Laurentia are genetically related and share a common evolutionary history linked to breakup of a preRodinia supercontinent (Zhao et al., 2002). Other researchers favour links between Laurentia and Serbia (Sears et al., 2004). Here, we give a brief account of basin evolution in the late Paleoproterozoicearliest Mesoproterozoic sequences of the Mount Isa region along with a more tightly constrained kinematic and tectonic framework whereby the Paleoroterozoic rocks of eastern Australia might be further compared with their North American counterparts and used as a test of competing supercontinent reconstructions. Such comparisons have been carried out before but more usually in the context of Rodinia reconstructions, including AUSWUS (Australiawestern United States)(Burrett and Berry, 2000; Karlstrom et al., 2001) and SWEAT (SW United States-East Antarctica) (Dalziel, 1991;

Figure 1 (a) AUSWUS versus SWEAT reconstruction of Australian and Laurentian rifted margins for Neoproterozoic time. SWEAT restores Australia (dotted outline) and Mount Isa to much the same position opposite NW Canada as existed at the time of the Paleoproterozoic Nuna supercontinent. (b) More detailed AUSWUS reconstruction (Burrett and Berry, 2000) with Broken Hill Block juxtaposed against terranes of equivalent age and isotopic composition in southern Laurentia. WB=Wernecke Basin.
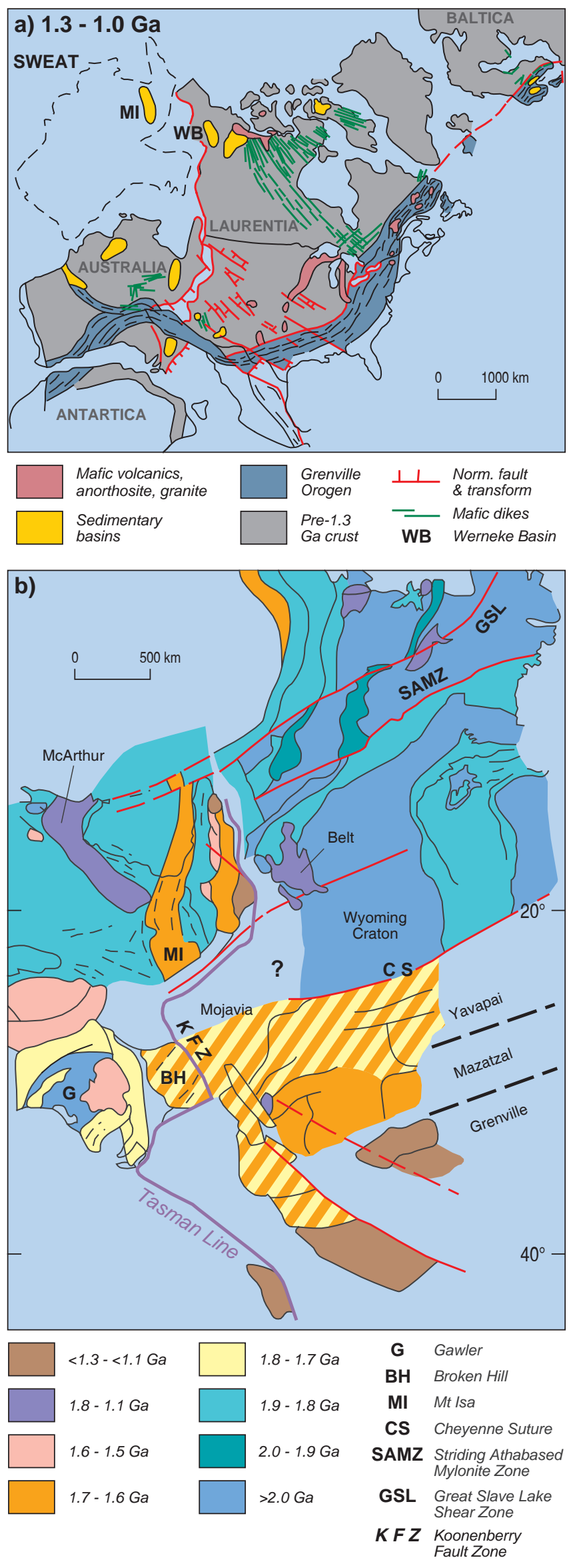

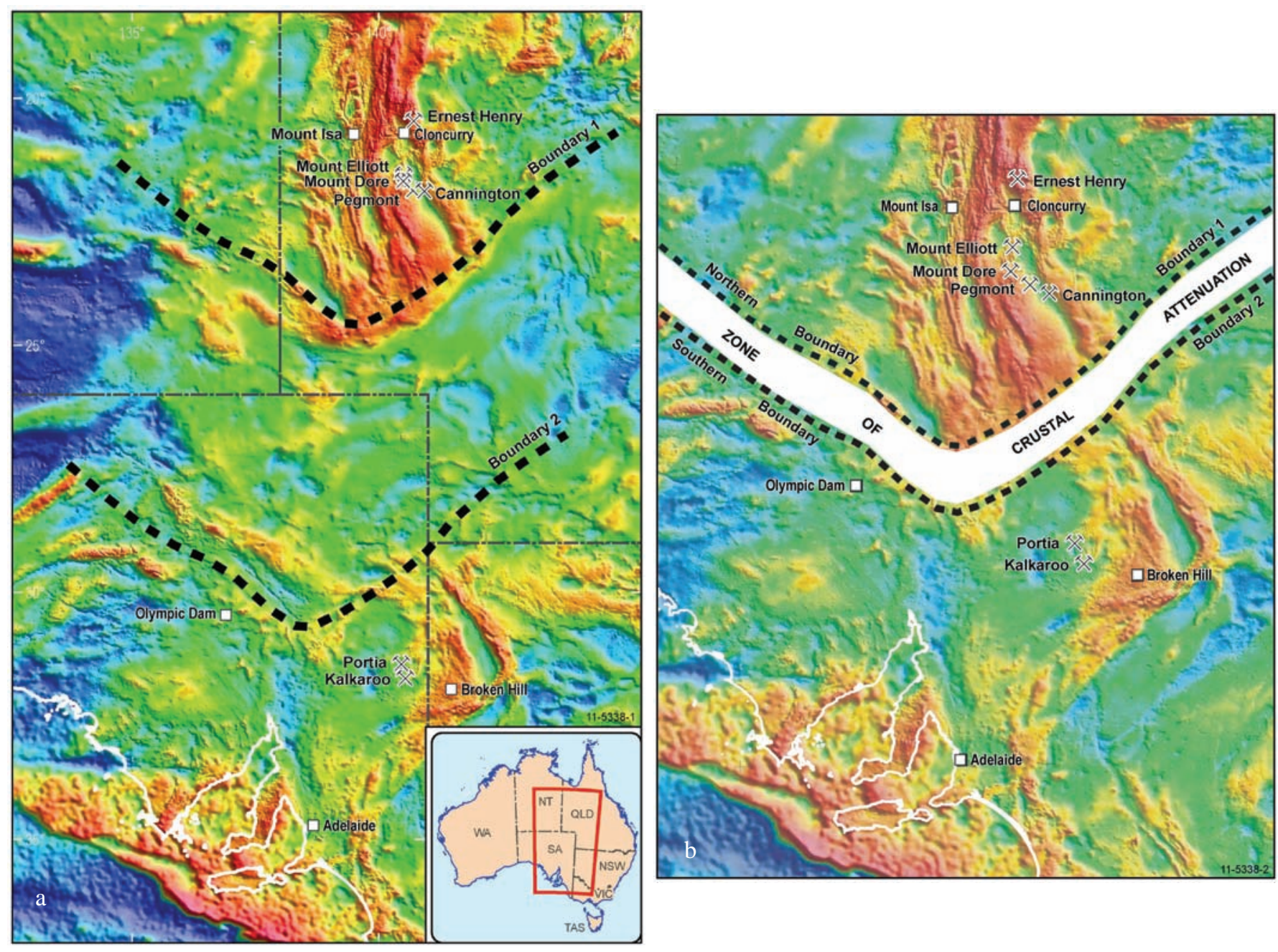

Figure 2 (a) Uninterpreted gravity anomaly image with Mount Isa and Broken Hill in present-day configuration. (b) Gravity image with Broken Hill basement terrane restored to its pre-Rodinia breakup position opposite the Mount Isa region (after Henson et al., 2011). Note coincidence of Cloncurry-Cannington and Broken Hill gravity trends.

Moores, 1991) where the primary constraint on reconstruction was not the distribution of the Paleoproterozoic-Mesoproterozoic rift basins but the orogenic belts of Grenville-age along which supercontinent assembly is interpreted to have taken place (Figure 1).

\section{Regional geology and tectonic setting of the Mount Isa region}

The Mount Isa region (Figure 3) combines an older crystalline basement (Kalkadoon-Leichhardt Block) affected by the $\geq 1840 \mathrm{Ma}$ Paleoproterozoic Barramundi Orogeny with three variably deformed and vertically stacked superbasins ranging in age from 1790-1575 Ma (Leichhardt, Calvert and Isa superbasins). Equivalents of the Kalkadoon-Leichhardt Block and Leichhardt Superbasin have yet to be identified in Broken Hill even though there are good geological and geophysical grounds for concluding that the two terranes were once continuous with each other (Figure $2 \mathrm{~b}$ ) and evolved in a common tectonic environment (Betts et al., 2011; Gibson et al., 2008; Giles et al., 2002; Henson et al., 2011). Orogenesis in both regions peaked around 1600-1585 Ma (Isa and Olary orogenies) and obscures an earlier history of syn-extensional magmatism, deformation and low pressure-high temperature metamorphism linked to basin formation and normal faulting at higher crustal levels (Conor and Preiss, 2008; Forbes et al., 2008; Gibson and Nutman, 2004; Gibson et al., 2008; Neumann et al., 2009; Page et al., 2005).

Some researchers (Gibson et al., 2008; Holcombe et al., 1991; Passchier, 1986; Passchier and Williams, 1989) have also argued that basin evolution in the Mount Isa terrane was linked at depth to the formation of extensional shear zones best exposed $\mathrm{E}$ of the KalkadoonLeichhardt Block (Wonga Extensional Belt), inviting comparison with the North American Basin and Range Province where such linkages have been more comprehensively documented (Wernicke, 1985). Nevertheless, it is evident that such comparisons cannot be carried too far because the youngest extensional shear zones at Mount Isa formed no later than $1670 \mathrm{Ma}$ (Gibson et al., 2008; Neumann et al., 2006) and thus relatively early in basin history. A further 70-80 Myr of predominantly deep water marine sedimentation followed, possibly linked to post-extensional thermal subsidence. This and other aspects of basin formation indicate that the Mount Isa terrane is not simply a deformed intra-continental rift or continental back-arc basin (Giles et al., 2002) but shares many similarities with present-day rifted continental margins and evolved almost to the point of sea-floor spreading. In the absence of any direct evidence for seafloor spreading 


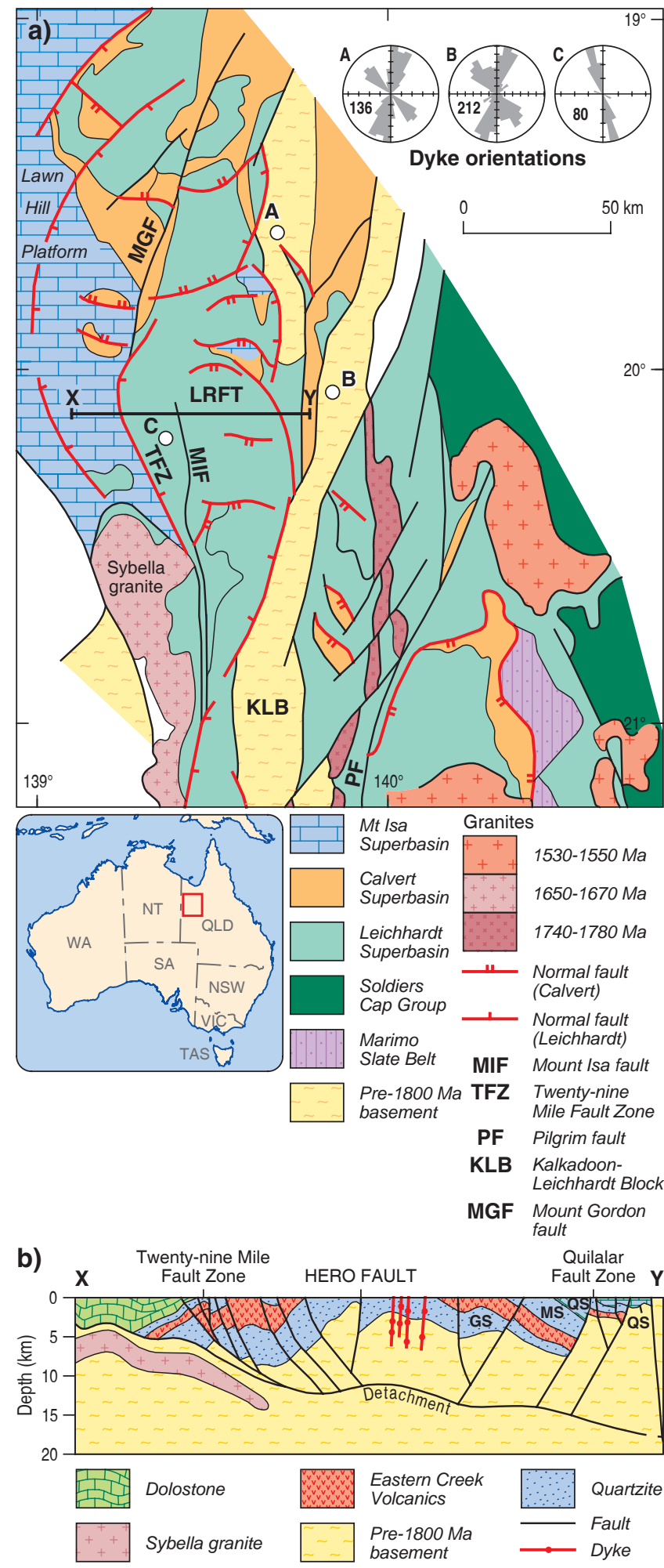

Figure 3 Simplified geologic map and section for northern part of Leichhardt River Fault Trough (LRFT). Note switch in direction of stratal thickening into Quilalar and Twenty-nine Mile Fault zones at c. $1775 \mathrm{Ma}$, and parallelism between measured dike orientations (insets $A, B$ and $C$ ) and normal fault trends in the LRFT and adjacent Kalkadoon-Leichhardt basement block.QS = Quilalar Supersequence; MS = Myally Supersequence; $G S=$ Guide Supersequence in the Mount Isa region itself, rifting may have stepped further outboard and been re-established E of Georgetown (Baker et al., 2010) where continental breakup actually took place, possibly as late as $1650 \mathrm{Ma}$ and no earlier than $1670 \mathrm{Ma}$ (cf. Betts and Giles, 2006).

\section{Basin history of Mount Isa region}

The Leichhardt, Calvert and Isa superbasins each comprise several unconformity-bounded sedimentary packages or supersequences (Jackson et al., 2000; Southgate et al., 2000). These include both syn- and post-rift packages (Betts and Giles, 2006; Blake, 1987; Eriksson et al., 1993; O’Dea et al., 1997) although opinion remains divided about basin architecture and the kinematic framework in which successive packages were deposited. Many of these same packages are recognised here (Figure 4) but with different conclusions drawn regarding basin evolution and tectonic history. Unlike some earlier studies, no definitive evidence was obtained for widespread basin inversion between deposition of the Leichhardt and Calvert superbasins (Betts, 1999, 2001). Instead, a major unconformity between successive extensional regimes is recognised across which there was a switch in the principal extensional direction from ENEWSW to NE-SW (Figure 4). This switch brought about a major change in the pattern of sedimentation from c. $1730 \mathrm{Ma}$ onward (Figure 4), and superimposed a differently oriented set of extensional structures on a pre-existing rift template (Leichhardt Superbasin). Deep seismic reflection profiles across Mount Isa support the case for a change in extensional direction between deposition of the Leichhardt and Calvert superbasins and show little evidence for significant basin inversion before c. $1640 \mathrm{Ma}$ (Gibson et al., 2010; Queensland Geological Survey, 2011). Basin inversion at this time is further supported by a prominent $1640 \mathrm{Ma}$ hairpin bend in the $\mathrm{N}$ Australia polar wander path (Idnurm, 2000) and corresponding change in sedimentation patterns (Southgate et al., 2000).

Further deformation and inversion of basin architecture occurred during crustal shortening and strike-slip faulting accompanying the polyphase 1600-1550 Ma Isa Orogeny but to different degrees on either side of the Kalkadoon-Leichhardt Block which trends N-S and subdivides the Mount Isa region into western and eastern successions (Figure 3). Eastern succession rocks preserve much less of the original basin architecture and have generally undergone deeper burial and more intense deformation than rocks of the same age farther W: peak metamorphism in these rocks occurred at c. $1585 \mathrm{Ma}$ and ranges up to the amphibolite facies whereas greenschist to sub-greenschist facies conditions predominate in the western succession (Foster and Austin, 2008; Rubenach et al., 2008). Together, the eastern and western successions represent an oblique section through the crust whereby structures formed at mid-crustal depths (eastern succession) can be compared to structures formed at higher structural levels in the $\mathrm{W}$.

\section{Leichhardt Superbasin (1800-1750 Ma)}

The Leichhardt Superbasin (Figure 4) developed between 1800$1750 \mathrm{Ma}$ (Neumann et al., 2006) and is best known from the Leichhardt River Fault Trough (LRFT) and southern Lawn Hill Platform (Figure 3) where some 5-7 km of continental flood basalts (Eastern Creek Volcanics) and syn-rift sediments accumulated in an elongate, fault-bounded basin 50-80 km wide (Blake, 1987; Derrick, 1982; Eriksson et al., 1993; Jackson et al., 2000; Scott et al., 2000). 


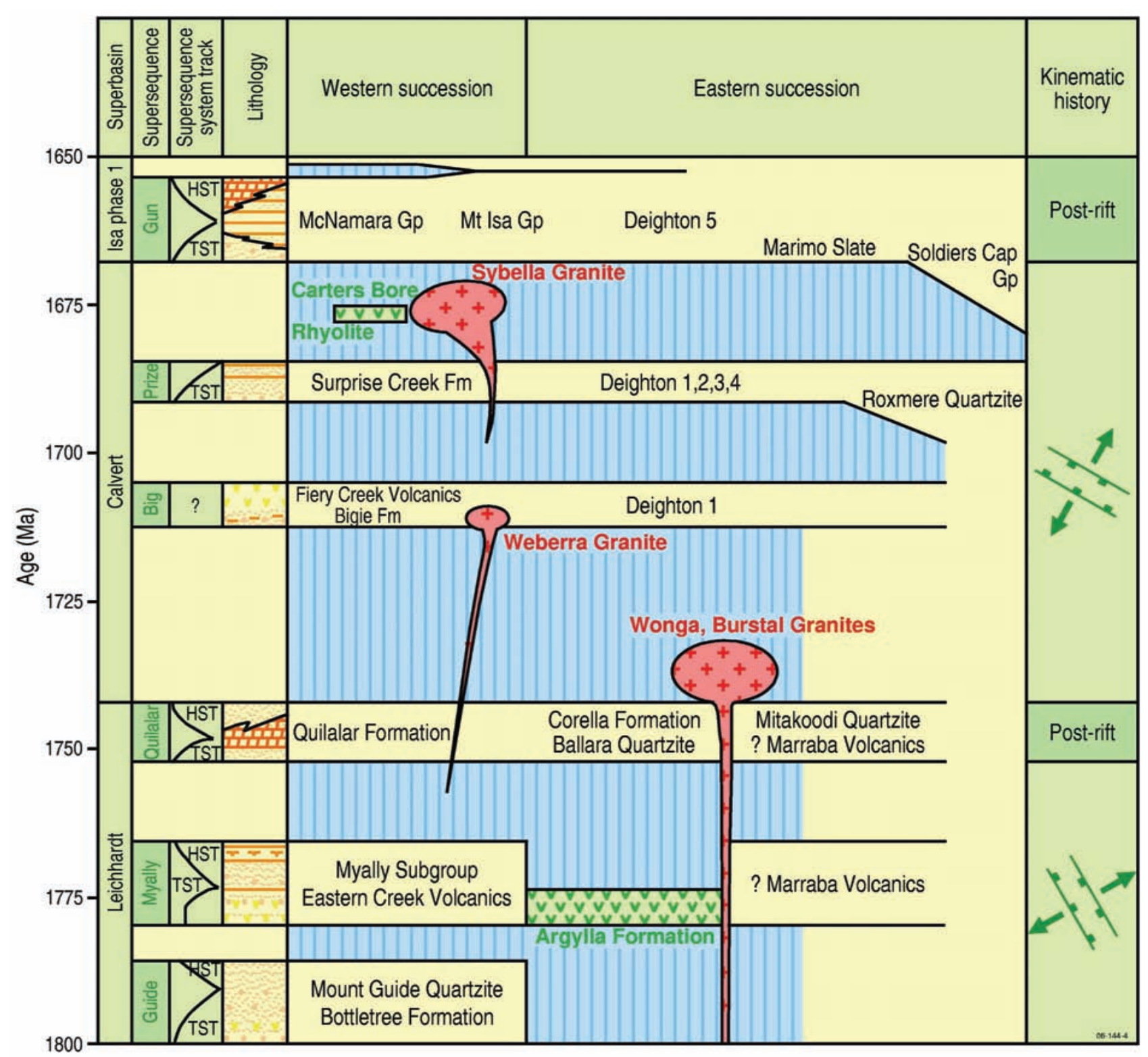

Figure 4 Chronostratigraphy and interpreted kinematic history for Leichhardt, Calvert and lowermost part of Isa superbasins in Mount Isa region.

Basin-bounding faults trend NNW and belong to a family of steep, mainly inward-dipping growth faults across which there has been appreciable vertical displacement resulting in half-graben formation (Gibson et al., 2008) and abrupt changes in sedimentary and volcanic thicknesses from the hanging to footwall (Figures 3, 5 and 6). Hangingwall displacements typically range from 100s of metres to a few kilometres (Figure 3) but despite such displacements, topographic relief appears to have been subdued with no evidence for the existence of deep water sedimentary basins. Rather, environmental conditions favoured the deposition of fluviatile to lacustrine sedimentary packages (Guide and Myally supersequences; Figure 4) in which crossand trough-bedded quartzite and feldspathic sandstone are the dominant lithologies. Red beds with minor amounts of intercalated stromatolitic dolostone (Lochness Formation) commonly occur towards the top of the Myally Supersequence (Figure 4) and most likely represent local excursions into evaporitic or shallow marine conditions (Derrick, 1982; Jackson et al., 2000). Individual halfgraben within the Leichhardt Superbasin have dimensions comparable to modern rift basins (Bosworth, 1992) and are up to $70 \mathrm{~km}$ long and 30-50 km wide (Figure 3).

Basaltic rocks and interbedded siliciclastic sediments of the 1780-1775 Ma Eastern Creek Volcanics (Figure 4) thicken westwards in the LRFT (Bain et al., 1992; Gibson et al., 2008) and are not known to occur any farther $\mathrm{W}$ than the Twenty-nine Mile fault zone (Figure 3). The basalts were extruded under subaerial or shallow water conditions. Their inferred correlatives in the eastern succession are basaltic lava flows of the Marraba Volcanics which are similarly overlain by shallow water quartzite and sandstones (e.g., lower Mitakoodi Quartzite) and contain some layers of clastic sediment (Figure 4). A few interbeds of shallow marine stromatolitic dolostone have been observed within the Marraba Volcanics near its base although in most other respects the depositional environment in the eastern succession at this time does not appear to have been appreciably different to that in the western succession. Felsic volcanic rocks (Argylla Formation) with ages of 1760 and $1780 \mathrm{Ma}$ (Neumann et al., 2009; Page, 1983) at the base of the eastern succession have 
been widely interpreted as former ignimbrites (Blake, 1987) but have no obvious compositional equivalent in the Eastern Creek Volcanics farther W. Notwithstanding this important difference, both the Argylla Formation and older parts of the Leichhardt Superbasin (Guide Supersequence) have been extensively intruded by dolerite dikes (now metamorphosed) with orientations that match the inferred direction of extension in the Leichhardt Superbasin (Figure 3).

Deposition of the Myally Supersequence was followed (Figure 4) in the western succession by an episode of thermally-induced regional subsidence, leading to marine transgression and burial of the syn-rift sequences beneath a sheet-like cover of fluviatile-shallow marine sediments dominated by clean, well-sorted quartzite and wellbedded, stromatalitic limestones and redeposited calcareous sandstones (Quilalar Supersequence). The eastern equivalents of these rocks (Figure 4) are the Ballara Quartzite and platform carbonate sequences of the Corella Formation (Blake, 1987; Derrick et al., 1980). Detrital zircon ages and intrusion of this platform sequence by the 1740 Ma Burstall Granite (Page, 1983) constrain the age of this marine package to between c. 1755-1740 Ma (Figure 4).

\section{Calvert Superbasin (1740-1670 Ma)}

Onset of rifting and localised uplift in the Calvert Superbasin is marked in the western succession by a major regional unconformity, deposition of fanglomerates and coarse sandstones in fault-angle depressions and fluviatile environments (Bigie Formation), and a rejuvenation of bimodal magmatism (Figure 4) including extrusion of the 1710 Ma Fiery Creek Volcanics (Hutton and Sweet, 1982; Jackson et al., 2000) and intrusion of the 1710 Ma Weberra Granite (Neumann et al., 2006). This was followed by several cycles of upward-fining, mainly siliciclastic sedimentation (Prize Supersequence; Figure 4), during the course of which the depositional environment changed from near-shore to deltaic or shallow marine (Hutton and Sweet, 1982; Southgate et al., 2000). With further deepening of the sedimentary basin(s), increasingly greater amounts of thinly laminated carbonaceous shale or rhythmite were deposited. Stratal thickening of these sequences into E- or NE-trending growth faults points to a syn-rift origin for much of the Calvert Superbasin (Betts et al., 1998; Derrick, 1982; Gibson et al., 2008; O'Dea et al., 1997). Magmatic rocks emplaced during the later stages of rifting include the $1678 \mathrm{Ma}$ Carters Bore Rhyolite and < $50 \mathrm{~cm}$ synsedimentary peperitic intrusions dated at c. 1690 Ma (Page et al., 2000). These dates provide the best available age constraint on sedimentation in the Calvert Superbasin and are only marginally older than the $1670 \mathrm{Ma}$ age obtained from the Sybella Granite (Neumann et al., 2006) which intrudes basement and/or the Eastern Creek Volcanics near the base of the underlying Leichhardt Superbasin (Figure 3).

Accompanying and/or immediately following the cessation of deposition in the Prize Supersequence (Figure 4), the main sedimentary depocentre shifted eastward into the region now occupied by the Soldiers Cap Group in the eastern succession. This group consists predominantly of metamorphosed deep water siliciclastic turbidites and intercalated carbonaceous sediments which have no direct lateral or temporal equivalent among the shallower water sedimentary facies preserved farther W in the LRFT (Figure 4). Rather, this sedimentary facies is restricted to the eastern succession where it has been intruded by basaltic dikes and sills, including variably metamorphosed 1685 Ma dolerite with highly evolved, Fe-enriched compositions (Baker et al., 2010). Compositionally, these mafic rocks resemble modern-day oceanic tholeiites or basalts extruded through thin sialic crust preceding continental breakup (Barberi et al., 1975; Sinton et al., 1983). Their magmatic age is identical to 1685 Ma detrital zircon ages obtained from their host rocks (Neumann et al., 2009), indicating that sedimentation, crustal thinning and basaltic intrusion were all coeval in at least part of the Soldiers Cap Group (Figure 4). Turbidite deposition in Soldiers Cap Group is consequently viewed here as a response to the same syn-rift extensional processes that gave rise to accommodation space now preserved as Prize Supersequence deposits in the LRFT, despite the slightly younger age (Figure 4) and consequent stratigraphic position above preserved Prize Supersequence in the LRFT. The absence of a preserved temporal equivalent may indicate that parts of the Prize Supersequence have been removed through erosion at the break-up unconformity and now reside farther E in the Soldiers Cap Group (Figure 5).

\section{Isa Superbasin (1670-1590 Ma)}

The Isa Superbasin is best represented on the Lawn Hill Platform (Figure 3) where it comprises $8 \mathrm{~km}$ of rhythmically-bedded turbidites, carbonaceous shales and stromatolitic dolostone deposited in a shallow to deep water marine environment (Hutton and Sweet, 1982; Krassay et al., 2000). Farther S, the basal component of this supersequence comprises a transgressive package of fluviatile to shallow marine sandstones, siltstones and dolostones with subordinate amounts of black shale represented by the lower parts of the Gun Supersequence (Southgate et al., 2000). This transgressive package rests unconformably on rocks of the Calvert Superbasin and is widely considered to be of post-rift origin (e.g., Jackson et al., 2000). However, unlike the older Quilalar Supersequence with which it shares many similarities, this transgressive package also shows clear evidence of stratal thickening into the same E-W-trending structures that controlled deposition of the underlying Calvert Superbasin (Southgate et al., 2000). Either these structures continued to be active during the marine transgression or they were simply buried along with any remaining accommodation space during thermal subsidence and deposition of the fluviatile-shallow marine sequence. Possible correlatives of the Isa Superbasin in the eastern succession include thinly laminated carbonaceous slates and siltstones of the Marimo Slate Belt which, like its inferred western correlatives, lacks coeval igneous intrusions.

\section{Basin evolution and detachment faulting}

Concomitant with initial basin evolution in the LRFT, mid-crustal extensional shear zones in the eastern succession (Figure 5) were intruded by bimodal magmatic rocks with ages ranging between 1740 1780 Ma (Gibson et al., 2008; Neumann et al., 2009; Pearson et al., 1991). These shear zones separate a locally exposed lower plate containing mylonitised 1780 Ma Argylla Formation from a brittle upper plate cut by normal faults that penetrate no higher than lowermost Corella Formation (Holcombe et al., 1991; Passchier, 1986). Footwall mylonites give a top-to-the-S or SW sense of shear (Pearson et al., 1991; Gibson et al., 2008) and are constrained by their magmatic host rocks to have formed no later than $1740 \mathrm{Ma}$ and possibly as early as $1780 \mathrm{Ma}$ (Neumann et al., 2009). More importantly, these data indicate that the mylonites and their associated 


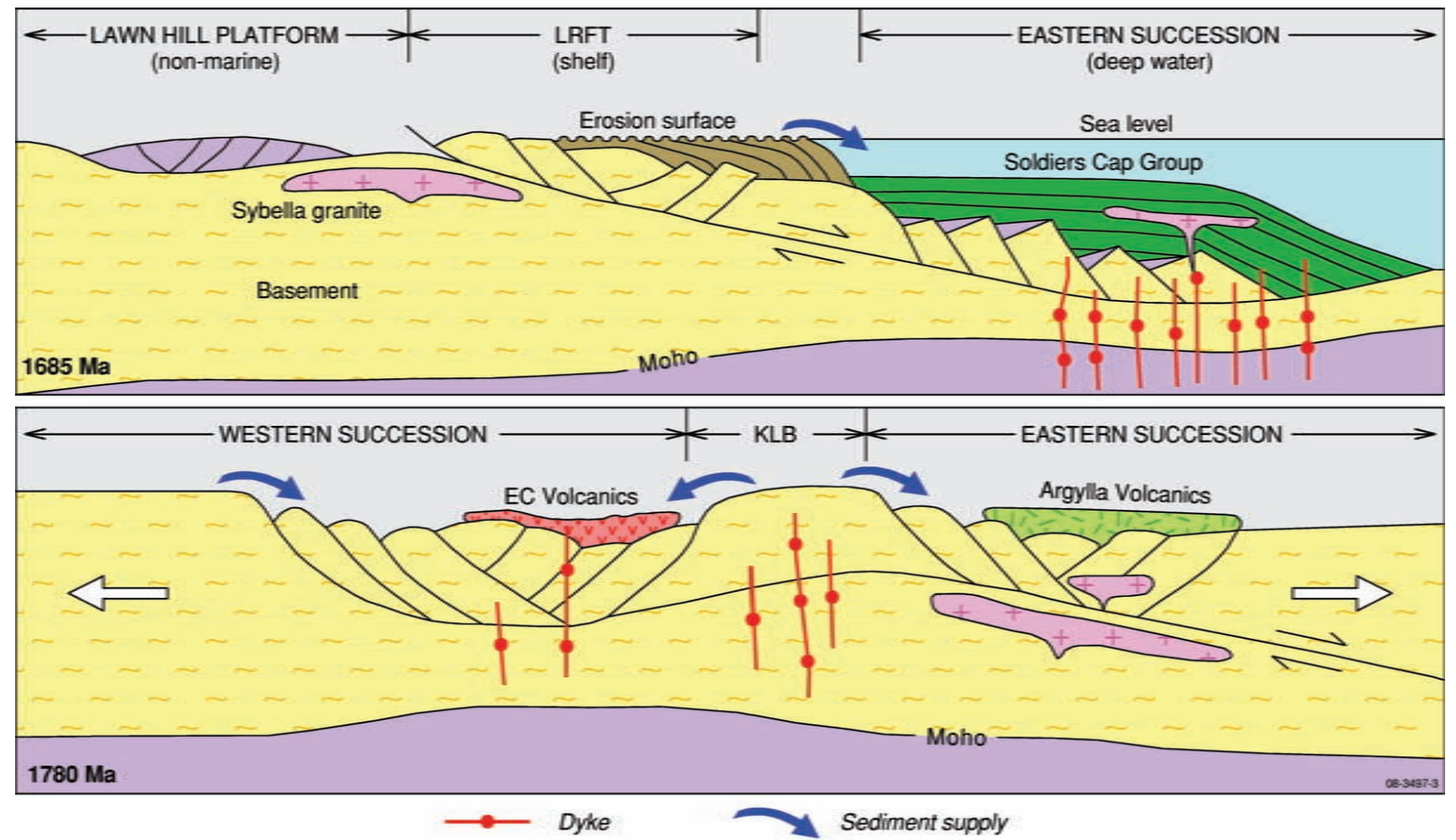

Figure 5 Generalised W-E crustal sections illustrating links between basin formation, magmatism and syn-extensional detachment faulting in Leichhardt (bottom) and Calvert superbasins (top). Note erosion and reworking of previously deposited platform and near-shore sequences (Prize Supersequence) to form deep water turbidites farther outboard (Soldiers Cap Group). Dolerite dikes are concentrated in region of greatest crustal thinning and deepest water sedimentation.

shear zones overlap in age with basaltic magmatism and basin formation at higher crustal levels in the Leichhardt Superbasin (Figure 5). A genetic as well as temporal relationship between half-graben formation, bimodal magmatism and development of these mid-crustal extensional detachments is indicated.

Half-graben formation, bimodal magmatism, and the formation of mid-crustal detachments beneath a brittle, extended upper plate are all features shared by other extensional terranes such as the North American Basin and Range Province (Wernicke, 1985). Particularly apt are comparisons with the Rio Grande Rift which shares a similar record of basaltic volcanism followed by fluviatile to lacustrine sedimentation in a narrow intracontinental rift (May and Russell, 1994). It serves as an excellent modern analogue for the Leichhardt Superbasin and, like the latter, comprises a series of half-graben bounded by normal faults that extend downward into a major detachment of extensional origin (Figure 6). Notwithstanding such striking similarities, there is no evidence that formation of the Leichhardt Superbasin was ever accompanied by uplift and the exhumation of metamorphic core complexes as was the case in the Basin and Range Province. Rather, the detachment and associated lower plate mylonites of the Leichhardt Superbasin (e.g., Double Crossing Metamorphics) remained buried until exhumed during a later phase of extension and/or by deformation accompanying the 1600 Ma Isa Orogeny.

By $1685 \mathrm{Ma}$, basin geometry in the Calvert Superbasin was well established, driven by NE-SW extension and accompanied in the eastern succession by intrusion of basaltic magmas (Figures 4 and 5) into deep marine basins filled by turbiditic sediments (Soldiers Cap Group) (Gibson et al., 2008). Farther W in the LRFT, near-shore, shallow water conditions persisted until arrested by a thermal perturbation at c. $1670 \mathrm{Ma}$ accompanying intrusion and extensional unroofing of the Sybella Granite and its country rocks from midcrustal depths (Gibson et al., 2008). Unroofing took place on an ENEdipping detachment surface (Figure 5) that brought about erosion and reworking of rocks belonging to the Leichhardt Superbasin and

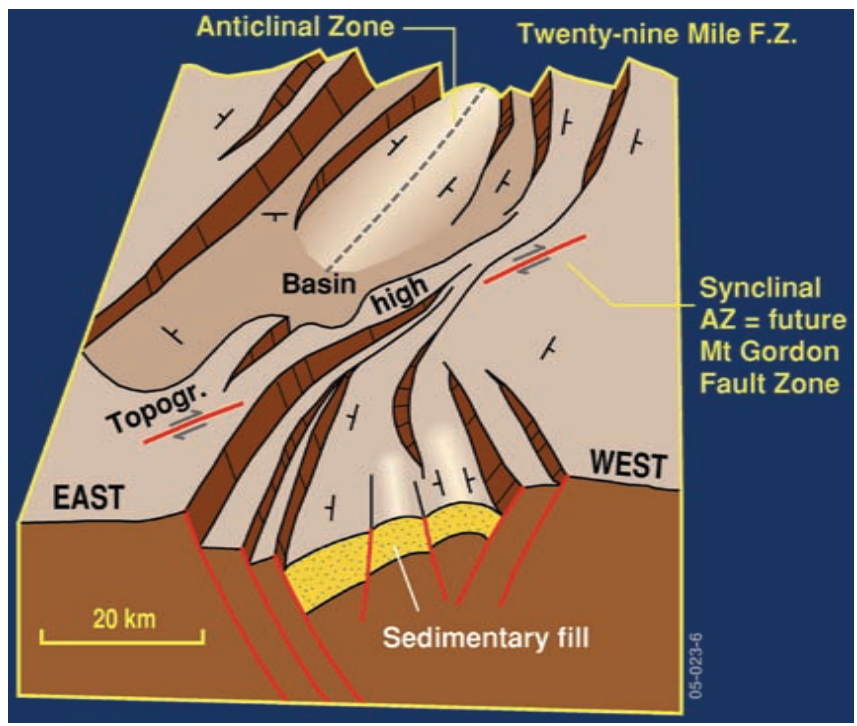

Figure 6 Schematic representation of basin architecture and fault geometry in the northern part of the Leichhardt River Fault Trough looking south. The future Mount Gordon Fault Zone formed along the accommodation zone (AZ) located between the two sub-basins. 
older parts of the Calvert Superbasin, and their subsequent redeposition in half-graben elsewhere in the basin. Shear fabrics in the Sybella Granite and rotated tilt blocks in Calvert age rocks above the detachment on which unroofing took place further indicate that extension during this stage of basin evolution involved displacement of the upper plate towards the ENE (Gibson et al., 2008) and thus on a detachment that dipped oceanward in the same direction as overall deepening of the sedimentary basin (Figure 5). Less obvious is whether this detachment is the same (reactivated) structure that accommodated extension and normal faulting during formation the older Leichhardt Superbasin. Oceanward-dipping detachments such as these are thought to underlie all sedimentary basins formed in continental margin settings and are a predictable consequence of asymmetric crustal extension and basin development (Lister et al., 1991). The Calvert Superbasin would appear to be a case in point, leading us to conclude that by $1670 \mathrm{Ma}$ basin geometry in the Mount Isa region had evolved beyond a simple intracontinental rift or Basin and Range-type setting into a fully-fledged back-arc basin in which the crust had become appreciably thinned and attenuated, possibly almost to the point of seafloor spreading. In keeping with this interpretation, basaltic rocks in the Leichhardt through to Calvert Superbasin (Eastern Creek Volcanics through Soldiers Cap Group) exhibit compositional changes consistent with extrusion through progressively thinner continental crust (Baker et al., 2010). Equally importantly, the Gun unconformity defining the base of the Isa Superbasin is markedly transgressive and bears a striking similarity to the continental breakup unconformities illustrated by Lister et al. (1991). This unconformity marked the onset of shallow marine conditions across much of the Mount Isa region and was followed by rapid deepening of the depositional environment with sedimentation thereafter dominated by open marine conditions and increasing deposition of turbidite sequences.

\section{Implications for reconstructions of the Nuna and Rodinia supercontinents}

Notwithstanding their obvious great difference in age, the Nuna and Rodinia supercontinents both assume that eastern Australia and western Laurentia represent conjugate rift margins (Betts et al., 2008, 2011; Dalziel, 1991; Karlstrom et al., 2001; Rogers and Santosh, 2009; Zhao et al., 2002). It follows that their constituent terranes were once contiguous and share a common geologic history. In this context, the 1800-1600 Ma history of intracontinental rifting and consequent rift margin formation outlined in this paper for Mount Isa and Broken Hill becomes important because the attendant events pre-date assembly of Rodinia and pertain only to the older Nuna supercontinent. This implies that the assumed longterm connectivity of 1800-1600 Ma orogenic belts between Australia and Laurentia inherent to the AUSWUS and SWEAT reconstructions of Rodinia is incorrect because the rocks in question are unlikely to have remained in their original pre-Rodinia configuration. Rather, following the breakup of Nuna, these rocks and their continental hosts would have dispersed before being reassembled in a different configuration during formation of Rodinia in the Neoproterozoic. A well constrained reconstruction of Rodinia based on matching events and orogenic belts of Grenville age need not work for older rocks such as those reported on here.

This is especially evident in the case of AUSWUS which provides a reasonable match between the Neoproterozoic rift basins of S-central
Australia and the southern United States (Figure 1b) but positions the 1800-1600 Ma continental rift basins of eastern Australia, and Broken Hill in particular, along strike from more juvenile accreted terranes of near-identical age in southern Laurentia (Burrett and Berry, 2000; Karlstrom et al., 2001). As pointed out by Betts et al. (2008), the 1800-1600 Ma basins of eastern Australia are more analogous to the basins of interior North America and thus better accommodated in a pre-Rodinia SWEAT-like configuration (Figure 1a) that matches the rocks of Mount Isa against NW Canada (cf. Thorkelson et al., 2001). In this interpretation, the Mojave, Yavapai and Mazatzal terranes have no connection with Broken Hill (Figure 1) and lie much farther S with respect to Australia, occupying a position off the East Antarctic Shield where 1700 Ma eclogites and other collisional rocks have been reported (Goodge et al., 2002). These collisional rocks were interpreted to have formed through the same tectonic processes that accompanied terrane accretion in southern Laurentia and were originally continuous with terranes of the same age developed along the southern margin of the North Australian Craton. In effect, these terranes and their North American counterparts formed a broad continuous belt of 1700-1650 Ma accreted terranes passing from southern Laurentia through Antarctica (Mawsonland) into southern and central Australia. As with the basins of Paleo-Mesoproterozoic age $\mathrm{N}$ of the Cheyenne Suture in Laurentia (Figure 1b), the temporally equivalent rift basins in the Mount Isa and Broken Hill regions formed through extension in a back-arc position located above a N-dipping subduction zone (Betts et al., 2008, 2011; Giles et al., 2002). Subduction roll-back, followed by the accretion of continental ribbons and successive juvenile terranes and/or magmatic arcs, were identified as the major drivers of orogenesis along the respective southern continental margins (Barth et al., 2000; Betts et al., 2008, 2011; Karlstrom and Bowring, 1988).

Whether similar far-field stresses could have produced the basins of similar age in NW Canada is not entirely clear although it is interesting to note that the late Paleoproterozoic-early Mesoproterozoic Wernecke Supergroup and Hornby Bay Group both developed on extended crystalline basement of similar age $(\geq 1840$ Ma) and magmatic character (MacLean and Cook, 2004; Thorkelson et al., 2005) to the Kalkadoon-Leichhardt Block of Mount Isa. As with Mount Isa, the Wernecke Basin (Figure 1a) also experienced basaltic magmatism at $1710 \mathrm{Ma}$ (Fiery Creek vs Bonnet Plume Intrusives) and orogenesis at $1600 \mathrm{Ma}$ (Isa vs Racklan orogeny). Further supporting a connection between the Paleoproterozoic sedimentary rocks of Mount Isa and NW Canada are strikingly similar detrital zircon (U-Pb) ages (Rainbird et al., 2007). Thorkelson et al. (2001) also suggested that the Quilalar Formation and Mary Kathleen Group at Mount Isa are sedimentary equivalents of basin fill in the Wernecke Basin although this makes no distinction between syn-and post-rift components and offers no explanation as to why the much thicker syn-rift sequences of the Leichhardt and Calvert superbasins are not more widely developed in western Canada. This may simply reflect the fact that much of the 1800 Ma western edge of the North American craton lies buried beneath younger rocks of Late Neoproterozoic-early Paleozoic age (Cook et al., 2005) and is only occasionally sufficiently deeply exhumed to expose the underlying late Proterozoic-early Mesoproterozoic basins as in eastern Australia.

Recently published gravity images (Henson et al., 2011) indicate that the late Paleoproterozoic-early Mesoproterozoic sequences of Broken Hill and Mount Isa were not only originally continuous along strike (Figure 2) but formed part of a much more regionally extensive 
belt of similarly aged rocks that extended southward along the eastern margin of the Gawler Craton (upper Hutchison and Walleroo Groups; Spzunar et al., 2011) into formerly adjacent parts of Antarctica (Peucat et al., 1999). This would imply that the rifted continental margins formed through the breakup of Nuna were oriented grossly N-S (present-day co-ordinates) and had a strike length of several thousand kilometres. Moreover, their orientation was almost orthogonal to the accreted terranes developed along the southern margins of Australia and Laurentia, ruling out any possibility that major Laurentian structures such as the Cheyenne Suture (Figure 1) originally extended into central Australia or has any correlative along the southern margin of the North Australian Craton (Gibson et al., 2008). Rather, the Laurentian terranes would appear to cut across the N-S trend of the Australian late Paleoproterozoic-Mesoproterozoic basins and possibly truncate them. The strike-length of these basins is such that any corresponding conjugate rift margin formed in western Canada at the time of Nuna breakup must be similarly well endowed in an impressive and regionally extensive set of late Paleoproterozoic-earliest Mesoproterozoic rift sequences over and above those currently known and exposed as inliers within the North American Cordillera.

\section{Acknowledgements}

The authors publish with permission of the Chief Executive Officers at Geoscience Australia and the Queensland Department of Employment, Economic Development and Innovation. We thank Geoff Derrick, Keith Scott, David Huston and Vladimir David for thoughtful and comprehensive reviews of the original manuscript. Bianca Reese (Geoscience Australia) drafted the figures.

\section{References}

Bain, J.H.C., Heinrich, C.A. and Henderson, G.A.M., 1992, Stratigraphy, structure and metasomatism of the Haslingden Group, East Moondarra area, Mount Isa: a deformed and mineralised Proterozoic multistage riftsag phase: AGSO Bulletin, v. 243, pp. 125-136.

Baker, M.J., Crawford, A.J. and Withnall, I.W., 2010, Geochemical, Sm-Nd isotopic characteristics and petrogenesis of Paleoproterozoic mafic rocks from the Georgetown Inlier, north Queensland: implcations for relationship with the Broken Hill and Mount Isa easterrn succession: Precambrian Research, v. 177, pp. 39-54.

Barberi, F., Ferrara, G., Santacroce, R., Treil, M. and Varet, J., 1975, A transitional basalt-pantellerite sequence of fractional crystallisation, the Boina Centre (Afar Rift, Ethiopia): Journal of Petrology, v. 16, pp. 2256.

Barth, A.P., Wooden, J.L., Coleman, D.S. and Fanning, C.M., 2000, Geochronology of the Proterozoic basement of southwesternmost North America, and the origin and evolution of the Mojave crustal province: Tectonics, v. 19, pp. 616-629.

Bell, R.T. and Jefferson, C.W., 1987, An hypothesis for an Australian-Canadian connection in the late Proterozoic and birth of the Pacific Ocean: Pacific Rim Congress, v. 87, pp. 39-50.

Betts, P.G., 1999, Palaeoproterozoic mid-basin inversion in the northern Mt Isa terrane, Queensland: Australian Journal of Earth Sciences, v. 46, pp. $735-748$.

Betts, P.G., 2001, Three-dimensional structure along the inverted Palaeoproterozoic Fiery Creek Fault System, Mount Isa terrane, Australia: Journal of Structural Geology, v. 23, pp. 1953-1969.

Betts, P.G., Lister, G.S. and O'Dea, M.G., 1998, Asymmetric extension of the Middle Proterozoic lithosphere, Mount Isa terrane, Queensland, Australia: Tectonophysics, v. 296, pp. 293-316.
Betts, P.G. and Giles, D., 2006, The 1800-1100 Ma tectonic evolution of Australia: Precambrian Research, v. 144, pp. 92-125.

Betts, P.G., Giles, D. and Schaefer, B.F., 2008, Comparing 1800-1600 Ma accretionary and basin processes in Australia and Laurentia: Possible geographic connections in Columbia: Precambrian Research, v. 166, pp. 81-92.

Betts, P.G., Giles, D. and Aitken, A., 2011, Paleoproterozoic accretion processes of Australia and comparisons with Laurentia: International Geology Review, v. 53, pp. 1357-1376.

Blake, D.H., 1987, Geology of the Mount Isa Inlier and environs, Queensland and Northern Territory: BMR Bulletin, v. 225, 83 pp.

Bosworth, W., 1992, Mesozoic and early Tertiary rift tectonics in East Africa: Tectonophysics, v. 209, pp. 115-137.

Burrett, C. and Berry, R.F., 2000, Proterozoic Australia-western United States (AUSWUS) fit between Laurentia and Australia: Geology, v. 28, pp. 103106.

Conor, C.H.H. and Preiss, W.V., 2008, Understanding the 1720-1640 Ma Palaeoproterozoic Willyama Supergroup, Curnamona Province, Southeastern Australia: Implications for tectonics, basin evolution and ore genesis: Precambrian Research, v. 166, pp. 297-317.

Cook, F.A., Hall, K.W. and Lynn, C.E., 2005, The edge of northwestern North America at ca. 1.8 Ga: Canadian Journal of Earth Sciences, v. 42, pp. 983-997.

Dalziel, I.W.D., 1991, Pacific margins of Laurentia and East AntarcticaAustralia as a conjugate rift pair; evidence and implications for an Eocambrian supercontinent: Geology, v. 19, pp. 598-601.

Derrick, G.M., 1982, A Proterozoic rift zone at Mount Isa, Queensland, and implications for mineralisation: BMR Journal of Australian Geology and Geophysics, v. 7, pp. 81-92.

Derrick, G.M., Wilson, I.H. and Sweet, I.P., 1980, The Quilalar and Surprise Creek Formations - new Proterozoic units from the Mount Isa Inlier (Australia) and their regional sedimentology and application to regional correlation: BMR Journal of Australian Geology and Geophysics, v. 5, pp. 215-223.

Duebendorfer, E.M. and Houston, R.S., 1987, Proterozoic accretionary tectonics at the southern margin of the Archean Wyoming Craton: Geological Society of America, Bulletin, v. 98, pp. 554-568.

Eriksson, K.A., Simpson, E.L. and Jackson, M.J., 1993, Stratigraphical evolution of a Proterozoic syn-rift to post-rift basin: constraints on the nature of lithospheric extension in the Mount Isa Inlier, Australia: International Association of Sedimentologists, Special Publication, v. 20, pp. 203-221.

Ernst, R.E., Wingate, M.T.D., Buchan, K.L. and Li, Z.X., 2008, Global record of 1600-700 Ma Large Igneous Provinces (LIPs): Implications for the reconstruction of the proposed Nuna (Columbia) and Rodinia supercontinents: Precambrian Research, v. 160, pp. 159-178.

Forbes, C.J., Betts, P.G., Giles, D. and Weinberg, R., 2008, Reinterpretation of the tectonic context of high-temperature metamorphism in the Broken Hill Block, NSW, and implications on the Palaeo- to Meso-Proterozoic evolution: Precambrian Research, v. 166, pp. 338-349.

Foster, D.R.W. and Austin, J.R., 2008, The 1800-1610 Ma stratigraphic and magmatic history of the Eastern Succession, Mount Isa Inlier, and correlations with adjacent Paleoproterozoic terranes: Precambrian Research, v. 163, pp. 7-30.

Gibson, G.M. and Nutman, A.P., 2004, Detachment faulting and bimodal magmatism in the Palaeoproterozoic Willyama Supergroup, south-central Australia: keys to recognition of a multiply deformed Precambrian metamorphic core complex: Journal of the Geological Society, v. 161, pp. 55-66.

Gibson, G.M., Rubenach, M.J., Neumann, N.L., Southgate, P.N. and Hutton, L.J., 2008, Syn- and post-extensional tectonic activity in the Palaeoproterozoic sequences of Broken Hill and Mount Isa and its bearing on reconstructions of Rodinia: Precambrian Research, v. 166, pp. 350369 .

Gibson, G.M., Hutton, L.J., Korsch, R.J., Huston, D.L., Murphy, B.J., Withnall, I.W., Jupp, B. and Stewart, L., 2010, Deep seismic reflection imaging of 
a Paleoproterozoic-Early Mesoproterozoic rift basin succession and related $\mathrm{Pb}-\mathrm{Zn}$ mineral province: the Mount Isa Inlier, in Proceedings 14th International Symposium on Deep Seismic Profiling of the Continents and their Margins, Cairns, 2010: Geoscience Australia, Record 2010/24, 50 pp.

Giles, D., Betts, P.G. and Lister, G.S., 2002, Far-field continental back-arc setting for the 1.80-1.67 Ga basins of northern Australia: Geology, v. 30, pp. 823-826.

Goodge, J.W., Myrow, P., Williams, I.S. and Bowring, S.A., 2002, Age and Provenance of the Beardmore Group, Antarctica: Constraints on Rodinia Supercontinent Breakup: The Journal of Geology, v. 110, pp. 393-406.

Henson, P.A., Kositcin, N. and Huston, D.L., 2011, Broken Hill and Mount Isa: linked but not rotated: AUSGEONews, v. 102, pp. 1-5.

Holcombe, R.J., Pearson, P.J. and Oliver, N.H.S., 1991, Geometry of a Middle Proterozoic extensional decollement in north-eastern Australia: Tectonophysics, v. 191, pp. 255-274.

Hutton, L.J. and Sweet, I.P., 1982, Geological evolution, tectonic style and economic potential of the Lawn Hill Platform cover, northwest Queensland: BMR Journal of Australian Geology and Geophysics, v. 7, pp. 125-134.

Idnurm, M., 2000, Towards a high resolution Late Palaeoproterozoic - earliest Mesoproterozoic apparent polar wander path for northern Australia: Australian Journal of Earth Sciences, v. 47, pp. 405-429.

Jackson, M.J., Scott, D.L. and Rawlings, D.J., 2000, Stratigraphic framework for the Leichhardt and Calvert Superbasins: review and correlations of the pre- 1700 Ma successions between Mt Isa and McArthur River: Australian Journal of Earth Sciences, v. 47, pp. 381-403.

Karlstrom, K.E. and Bowring, S.A., 1988, Early Proterozoic assembly of tectonostratigraphic terranes in southwestern North America: Journal of Geology, v. 96, pp. 561-576.

Karlstrom, K.E., Ahall, K.-I., Harlan, S.S., Williams, M.L., McLelland, J. and Geisman, J.W., 2001, Long-lived (1.8-1.0 Ga) convergent orogen in southern Laurentia, its extension to Australia and Baltica, and implications for refining Rodinia: Precambrian Research, v. 111, pp. 5-30.

Krassay, A.A., Domagala, J., Bradshaw, B.E. and Southgate, P.N., 2000, Lowstand ramps, fans and deep-water Palaeoproterozoic and Mesoproterozoic facies of the Lawn Hill Platform: the Term, Lawn, Wide and Doom Supersequences of the Isa Superbasin, northern Australia: Australian Journal of Earth Sciences, v. 47, pp. 563-597.

Laing, W.P., 1996, The Diamantina orogen linking the Willyama and Cloncurry Terranes, eastern Australia, in Pongratz, J. and Davidson, G. J., (eds), New developments in Broken Hill type deposits: CODES Special Publication 1, pp. 67-72.

Lister, G.S., Etheridge, M.A. and Symonds, P.A., 1991, Detachment models for the formation of passive continental margins: Tectonics, v. 10, pp. 1038-1064.

MacLean, B.C. and Cook, D.G., 2004, Revisions to the Paleoproterozoic Sequence A, based on reflection seismic data across the western plains of the Northwest Territories, Canada: Precambrian Research, v. 129, pp. 271-289.

May, S.J. and Russell, L.R., 1994, Thickness of the syn-rift Santa Fe Group in the Albuquerque Basin and its relation to structural style, in Keller, G.R. and Cather, S.M., (eds), Basins of the Rio grande Rift: structure, stratigraphy, and tectonic setting, Geological Society of America, Special Paper 291, pp. 113-123.

Moores, E.M., 1991, Southwest U.S.-East Antarctic (SWEAT) connection: A hypothesis: Geology, v. 19, pp. 425-428.

Neumann, N.L., Southgate, P.N., Gibson, G.M. and McIntyre, A., 2006, New SHRIMP geochronology for the westwern fold belt of the Mount Isa Inlier: developing a 1800-1650 Ma event framework: Australian Journal of Earth Sciences, v. 53, pp. 1023-1039.

Neumann, N.L., Gibson, G.M. and Southgate, P.N., 2009, New SHRIMP age constraints on the timing and duration of magmatism and sedimentation in the Mary Kathleen Fold Belt, Mt Isa Inlier, Australia: Australian Journal of Earth Sciences, v. 56, pp. 965-983.

O’Dea, M.G., Lister, G.S., Maccready, T., Betts, P.G., Oliver, N.H.S., Pound,
K.S., Huang, W., Valenta, R.K., Oliver, N.H.S. and Valenta, R.K., 1997, Geodynamic evolution of the Proterozoic Mount Isa terrain: Geological Society, London, Special Publications, v. 121, pp. 99-122.

Page, R.W., 1983, Chronology of magmatism, skarn formation, and uranium mineralization, Mary Kathleen, Queensland, Australia: Economic Geology, v. 78, pp. 838-853.

Page, R.W., Jackson, M.J., and Krassay, A.A., 2000, Constraining sequence stratigraphy in north Australian basins: SHRIMP U-Pb zircon geochronology between Mt Isa and McArthur River: Australian Journal of Earth Sciences, v. 47, pp. 431-459.

Page, R.W., Conor, C.H.H., Stevens, B.P.J., Gibson, G.M., Preiss, W.V. and Southgate, P.N., 2005, Correlation of Olary and Broken Hill Domains, Curnamona Province: Possible Relationship to Mount Isa and Other North Australian Pb-Zn-Ag-Bearing Successions: Economic Geology, v. 100, pp. 663-676.

Park, J.K., Buchan, K.L. and Harlan, S.S., 1995, A proposed giant radiating dike swarm fragmented by the separation of Laurentia and Australia based on paleomagnetism of ca. 780 Ma mafic intrusions in western North America: Earth and Planetary Science Letters, v. 132, pp. 129-139.

Passchier, C.W., 1986, Evidence for early extensional tectonics in the Proterozoic Mount Isa Inlier, Queensland, Australia: Geology, v. 14, pp. 1008-1011.

Passchier, C.W. and Williams, P.R., 1989, Proterozoic extensional deformation in the Mount Isa Inlier, Queensland, Australia: Geological Magazine, v. 126 , pp. $43-53$.

Pearson, P.J., Holcombe, R.J. and Page, R.W., 1991, Synkinematic emplacement of the middle Proterozoic Wonga Batholith into a midcrustal shear zone, Mount Isa Inlier, Queensland, Australia, in Stewart, A.J. and Blake, D.H. (eds), Detailed studies of the Mount Isa Inlier: Australian Geological Survey Organisation, Bulletin 243, pp. 289-328.

Peucat, J.J., Ménot, R.P., Monnier, O. and Fanning, C.M., 1999, The Terre Adélie basement in the East-Antarctica Shield: geological and isotopic evidence for a major $1.7 \mathrm{Ga}$ thermal event; comparison with the Gawler Craton in South Australia: Precambrian Research, v. 94, pp. 205-224.

Queensland Geological Survey, 2011, North-West Queensland Mineral and Energy province Report, 2011: Brisbane, Queensland Department of Employment, Economic Development and Innovation, 123 pp.

Rainbird, R.H., Stern, R.A., Rayner, N., and Jefferson, C.W., 2007, Age, provenance and regional correlation of the Athabasca Group, Saskatchewan and Alberta, constrained by igneous and detrital zircon geochronology, in Jefferson, C. W., and Delaney, G., (eds), EXTECH IV: Geology and Uranium EXploration TECHnology of the Proterozoic Athabasca Basin, Saskatchewan and Alberta: Geological Survey of Canada, Bulletin 588, pp. 1-17.

Rogers, J.J.W. and Santosh, M., 2009, Tectonics and surface effects of the supercontinent Columbia: Gondwana Research, v. 15, pp. 373-380.

Rubenach, M.J., Foster, D.R.W., Evins, P.M., Blake, K.L. and Fanning, C.M., 2008, Age constraints on the tectonothermal evolution of the Selwyn Zone, Eastern Fold Belt, Mount Isa Inlier: Precambrian Research, v. 163, pp. 81-107.

Scott, D.L., Rawlings, D.J., Page, R.W., Tarlowski, C.Z., Idnurm, M., Jackson, M.J. and Southgate, P.N., 2000, Basement framework and geodynamic evolution of the Palaeoproterozoic superbasins of north-central Australia: an integrated review of geochemical, geochronological and geophysical data: Australian Journal of Earth Sciences, v. 47, pp. 341-380.

Sears, J.W., Price, R.A. and Khudoley, A.K., 2004, Linking the Mesoproterozoic Belt-Purcell and Udzha basins across the west Laurentia-Siberia connection: Precambrian Research, v. 129, pp. 291308.

Sinton, J.M., Wilson, D.S., Christie, D.M., Hey, R.M. and Delaney, J.R., 1983, Petrologic consequences of rift propagation on oceanic spreading ridges: Earth and Planetary Science Letters, v. 62, pp. 193-207.

Southgate, P.N., Bradshaw, B.E., Domagala, J., Jackson, M.J., Idnurm, M., Krassay, A.A., Page, R.W., Sami, T.T., Scott, D.L., Lindsay, J.F., McConachie, B.A. and Tarlowski, C., 2000, Chronostratigraphic basin framework for Palaeoproterozoic rocks $(1730 \mathrm{Ma}-1575 \mathrm{Ma})$ in northern 
Australia and implications for base-metal mineralisation: Australian Journal of Earth Sciences, v. 47, pp. 461-483.

Spzunar, M., Hand, M., Barovich, K., Jagodzinski, E. and Belousova, E.A., 2011, Isotopic and geochemical constraints on the Paleoproterozoic Hutchinson Group, southern Australia: implications for Paleoproterozoic continental reconstructions: Precambrian Research, v. 187, pp. 99-126.

Thorkelson, D.J., Abbott, J.G., Mortensen, J.K., Creaser, R.A., Villeneuve, M.E., McNicoll, V.J. and Layer, P.W., 2005, Early and Middle Proterozoic evolution of Yukon, Canada: Canadian Journal of Earth Sciences, v. 42, pp. 1045-1071.

Thorkelson, D.J., Mortensen, J.K., Davidson, G.J., Creaser, R.A., Perez, W.A. and Abbott, J.G., 2001, Early Mesoproterozoic intrusive breccias in Yukon, Canada: the role of hydrothermal systems in reconstructions of

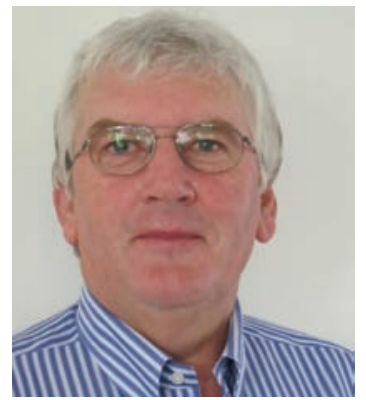

George M. Gibson is a graduate of Edinburgh and Otago universities with extensive research and leadership experience in the structure and tectonic evolution of Proterozoic orogenic belts, including Broken Hill and Mount Isa. Before joining Geoscience Australia in 1995, he was employed in the private and university sectors.

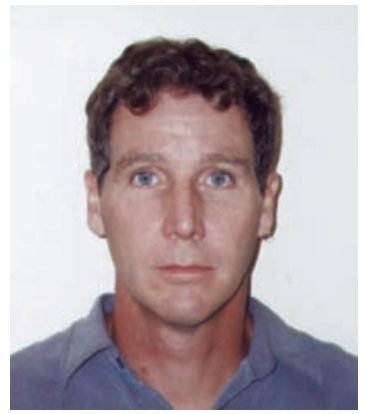

Paul A. Henson graduated from the University of Tasmania and is currently a research scientist at Geoscience Australia specialising in geology and geophysics. He took a lead role in the integration of structural geology and geodynamics into 3D maps and models for the Mount Isa and Yilgarn regions.

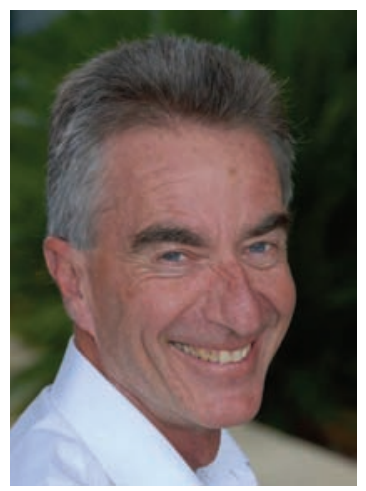

Peter N. Southgate completed his PhD in 1983 at the Research School of Earth Sciences at ANU. He has since worked as a basin analyst at Geoscience Australia. Between 1995 and 2005, he led and participated in research teams that developed a chronostratigraphic framework for the Mount Isa region.

North America and Australia: Precambrian Research, v. 111, pp. 31-55. Wang, X.-C., Li, Z.-X., Li, X.-H., Li, Q.-L. and Zhang, Q.-R., 2011, Geochemical and Hf-Nd isotope data of Nanhua rift sedimentary and volcaniclastic rocks indicate a Neoproterozoic continental flood basalt provenance: Lithos, v. 127, pp. 427-440.

Wernicke, B., 1985, Uniform-sense normal simple shear of the continental lithosphere: Canadian Journal of Earth Sciences, v. 22, pp. 108-125.

Wingate, M.T.D., Pisarevsky, S.A. and Evans, D.A.D., 2002, Rodinia connections between Australia and Laurentia: no SWEAT, no AUSWUS?: Terra Nova, v. 14, pp. 121-128.

Zhao, G., Cawood, P.A., Wilde, S.A. and Sun, M., 2002, Review of global 2.1-1.8 Ga orogens: implications for a pre-Rodinia supercontinent: Earth Science Reviews, v. 59, pp. 125-162.

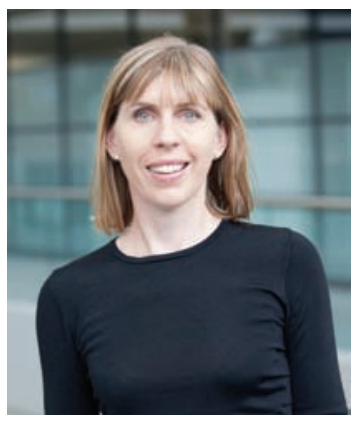

Narelle L. Neumann obtained her PhD from Adelaide University in 2001, focussing on Proterozoic granites and the links to high heat flow in South Australia. Since joining Geoscience Australia, she has specialised in the integration of geochronology with other geological datasets to better understand Australian Proterozoic terrains.

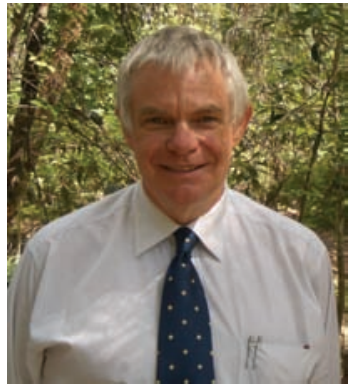

Laurie J. Hutton joined the Queensland Geological Survey in 1974 after graduating from Queensland University in 1972. He is an expert on the regional geology of northern Queensland and was team leader on the recently completed 2011 Northwest Queensland Mineral and Energy Province Study. He received his PhD in 2004. 